\title{
Claiming Their Education: The Impact of a Required Course for Academic Probation Students with a Focus on Purpose and Motivation
}

\author{
Molly Burke León \\ Indiana University Bloomington \\ moburke@indiana.edu \\ Anthony Guest-Scott \\ Indiana University Bloomington \\ Andrew Koke \\ Indiana University Bloomington \\ Stefano Fiorini \\ Indiana University Bloomington \\ Alexander Rangazas \\ Indiana University Bloomington
}

\begin{abstract}
This study assessed the impact of a course required of students placed on Academic Probation at a 4-year university. We focused our analysis on the 4,673 students who took the course as part of the 2008-2012 Fall cohorts, examining in detail the demographic composition of students taking the course as well as the timing of when the course was taken as related to its impact. Using logistic regression to control for a number of variables, we found that students who took the course as required were approximately 20\% more likely to persist and graduate compared to students placed on Academic Probation who did not take the course. These findings suggest that a course of this kind, credit-bearing and with a curriculum centered on helping students identify purpose and motivation for their higher education experience, may serve as a widely useful intervention for helping to dramatically increase the retention and graduation of students facing academic difficulty.
\end{abstract}

Keywords: academic difficulty, curricular intervention, student retention, graduation rates, college student success

\section{Introduction}

Widespread concern over college retention and graduation rates is becoming ever more urgent. As public worry over rising costs puts the spotlight on retention rates as a way to hold institutions accountable for the tax dollars and tuition they receive, decreases in state funding of public institution and rising operating costs mean that universities are facing budget shortfalls. Consequently, universities are facing mounting pressure to demonstrate their value and effectiveness, and more and more states are linking funding to demonstrated measures of success such as graduation and retention rates (Quinton, 2015; Stratford, 2015).

Beyond these contemporary financial concerns, however, students who seek a higher education degree deserve a fair chance to earn that degree and partake in all of the rights and privileges pertaining therein. Indeed, as Karen Hamman (2016) recently stated, institutions of higher learning have a "moral obligation" to give students whom they have admitted the best possible chance to 
graduate. Of particular interest, then, are students who experience academic difficulty and are placed on Academic Probation (defined here as having a cumulative GPA of below 2.0 on a 4.0 scale). Indeed, as many as one fourth of undergraduate college students will be placed on academic probation at least one time in their college careers, and one study of a community college indicated that as few as $13 \%$ of the students placed on academic probation will eventually graduate (Tovar and Simon, 2006; Cohen and Brawer, 2002; Garnett, 1990; Miller and Sonner, 1996). Once students fall into a status of Academic Probation, their chances of being retained and graduating diminish significantly, a situation that impacts not only institutional efficacy but also income. What are institutions doing to support these students, and what works?

A review of the literature suggests that academic retention is enhanced when, instead of blaming students, institutions demonstrate an attitude of caring and support and take responsibility for retention via wide-range programming (Salinitri, 2005; Thayer, 2000; Tinto, 2000; Walters, 2004). Braxton, Brier, and Steele (2007-2008) collated much of the existing outcome research and made some practical recommendations for best-practice interventions. In part they recommended the use of instructional approaches (e.g., orientations, workshops, or credit/noncredit classes) to serve first-year students, high-risk students, and or under-represented students. Suggested topics included orientation to policies and procedures, program requirements, study skills (e.g., test-taking skills, reading skills, critical thinking abilities), and career exploration. These recommendations also note the importance of using a broad range of support services (e.g., advising, counseling, mentoring, and tutoring) to complement instructional intervention in the aggressive pursuit of assisting with academic, personal, and career development (see also Turner and Thompson 2014).

Specific case studies at various universities illustrate and further nuance the effectiveness of these suggestions. Kamphoff, et al. (2006-2007), Mellor (2015), Hanger, et al. (2011) and Humphrey (2005), for example, have noted increased retention rates and higher GPAs when students participate in a class or regular group meeting. These classes may be required or voluntary, credit-bearing or noncredit-bearing. Most of these seminars involve a small group setting in which students not only learn new study skills, but also engage in meaningful reflection on student experience, aligning with research that emphasizes the importance of addressing extra-academic concerns (Salinitri, 2005; Tinto, 2000; Thayer, 2000). Many integrate a component of academic advising to help students feel more connected to their institution since students' sense of belonging to an institution is integral to their persistence (Astin, 1984; Cruise, 2002). These studies focus on student retention but do not follow the students through to their expected graduation dates, thus leaving room for research to show how these interventions impact students over the course of their educational trajectories. This is where our study of the EDUC-X158 course enters the conversation.

\section{The Phoenix Program and the Class: Description and Impact}

Indiana University Bloomington-the central campus of Indiana's flagship state university enrolling more than 40,000 students-has a longstanding tradition of supporting students who have been placed on Academic Probation. The University Division (UD), IUB's large, exploratory unit through which more than 5,000 students enter each year, has provided intensive academic probation programming in the form of the Phoenix Program since the early 2000s. In collaboration with the Student Academic Center, an academic support unit, the University Division requires students on Academic Probation to enroll in a credit-bearing course, EDUC-X158 "The Culture of College," and to meet twice with their academic advisors (who also make in-class presentations) as a part of the class. We include an essential peer-mentoring component, in which students who have formerly been on probation but have previously taken the class and regained good standing assist in the classroom,

Journal of the Scholarship of Teaching and Learning, Vol. 19, No. 4, October 2019. josotl.indiana.edu 
acting as role models and mentors to the students in the class, often teaching lessons and speaking from their own personal experiences.

Participation in this Phoenix Program is required for University Division students on Academic Probation. All literature describing the class and all official communications regarding probation requirements describe it as such. The class carries three credits and can be counted towards graduation as an elective. The requirement to take it, however, is enforced only through the placing of a hold on students' accounts that prevents them from registering early for the following semester. Therefore, a significant portion of students who are required to take the class elect not to take it with only minor consequences (a delayed opportunity to register for the next semester's classes).

In the EDUC-X158 probation seminar, we use a strengths-based approach to helping students explore their interests, pinpoint areas for improvement and practice new study and life management skills. Student attitudes and expectations have been found to be highly related to persistence and thus salient predictors of attrition and retention rates (Worrell and Hale, 2001; Dynarski \& Gleason, 2002). Hsieh, Sullivan, and Guerra (2007), for example, found that goal orientation and intentional selfefficacy prevailed among persistent students (see also Demetriou \& Schmitz-Sciborski, 2011). Building upon this research and extending it in practice, we facilitate reflection on students' purposes for seeking a higher education degree. In doing so, we invite a thorough analysis of our system of education, and attempt to awaken students to the many possible benefits of the liberal arts education that our institution provides. Since its inception, the class has included primary sources that engage students in the kind of complex thinking that will be required of them in their other classes. For example, "Claiming an Education," a speech given by poet Adrienne Rich at Rutgers' Douglass College in 1977, provides a vocabulary that truly serves as an awakening for many of our students. Rich's exhortation to claim rather than receive one's education and to take responsibility towards oneself obviously had a particular meaning at a women's college in 1977; however, students today find that the message inspires them to become active rather than passive learners. This move towards an active approach to education reinforces our attempt to teach a problem-solving mindset and to encourage students to see intelligence and ability as malleable vs. fixed, as Carol Dweck (2006) has noted.

In recent years, we have sought to make more explicit questions about the broad functions of higher education and students' own connections to that enterprise. Katharine Brooks' (2009) You Majored in What? Mapping Your Path from Chaos to Career offers rich and interactive opportunities for students to reflect on their interests and find ways to connect to those interests to what they learn in college and what they might do once they leave college. Articles such as selections from sociologist Inge Bell's (2013) This Book Is Not Required: An Emotional and Intellectual Survival Manual for Students and professor of American Studies Andrew Delbanco's (2012) College: What It Was, Is, and Should Be provide context for students' own positions within the larger university systems within which they find themselves struggling.

Other activities and assignments for the class include required visits to professors in other classes in addition to the required advisor visits, mentioned above, and a collaboration with our Career Development Center in which the CDC sends presenters to the classroom to work with students' career interests and a required visit with students' assigned career advisor. Students complete "note taking journals" on most reading assignments, and they create a final project in which they engage with the class materials and comment on how their view of and practice of education has changed. Finally, we prioritize human relationships in our classroom, doing many activities to promote a sense of community therein, as well as several individual conferences between the students and the graduate student instructor and undergraduate peer instructor.

Our research questions seek to measure the overall impact of this curriculum as a particular intervention and corrective action. Given that the EDUC-X158 course is designed to increase the retention and completion of undergraduate students placed on Academic Probation, to what extent

Journal of the Scholarship of Teaching and Learning, Vol. 19, No. 4, October 2019. josotl.indiana.edu 
are we meeting these objectives? And what are the differences in effect for those who take the course vs. those placed on Academic Probation who do not?

\section{Method}

We tracked probation and enrollments in EDUC-X158 from Fall 2008 to Spring 2015. For the fourteen semesters in this period a total of 6,425 students were required to take the course as a consequence of being placed on academic probation. In order to understand the impact of the course on the chances of successful academic progression beyond the sophomore year - the period at higher attrition in this institution (Feng et al., 2017) - we focused our analysis on probation students who were in the fall cohorts between 2008 and 2012, a total of 4,673 students. We created three cohorts by which to analyze all 4,673 students. First, "Matriculation Cohorts" allowed us to see how many students in any given year enrolled, as well as the demographic makeup of these cohorts. We also grouped students into "Probation Cohorts," allowing us to see how many students were placed on academic probation in their first semester, second semester, or subsequent semesters. Finally, "EDUC-X158 Cohorts" allowed us to see which students took the course and the timing of taking it relative to probation status, separated into three subgroups: 1) Immediate (Imm.) Takers (those who took it when they should have, which was the semester immediately after being placed on probation); 2) "Late-Takers", (those who took the course sometime later than that); and 3) "Non-Takers" (those who never took the course at all) - see Table 1.

Table 1. Timing of probation status versus EDUC-X158 enrollment status (Fall 2008-12 cohorts)

\begin{tabular}{|l|l|l|l|l|l|l|}
\hline \multicolumn{2}{|l|}{ Probation cohort group } & Non- \\
Takers & $\begin{array}{l}\text { Imm. } \\
\text { Takers }\end{array}$ & $\begin{array}{l}\text { Late-Takers } \\
\text { (2 Semesters) }\end{array}$ & $\begin{array}{l}\text { Late- } \\
\text { Takers } \\
\text { (More } \\
\text { Than 2) }\end{array}$ & Total \\
\hline First semester & Frequency & 1692 & 1367 & 167 & 96 & 3322 \\
\hline & Row Pct & 50.93 & 41.15 & 5.03 & 2.89 & \\
\hline & Col Pct & 69.66 & 71.53 & 84.34 & 71.11 & \\
\hline Second semester & Frequency & 412 & 377 & 17 & 24 & 830 \\
\hline & Row Pct & 49.64 & 45.42 & 2.05 & 2.89 & \\
\hline & Col Pct & 16.96 & 19.73 & 8.59 & 17.78 & \\
\hline After second semester & Frequency & 325 & 167 & 14 & 15 & 521 \\
\hline & Row Pct & 62.38 & 32.05 & 2.69 & 2.88 & \\
\hline & Col Pct & 13.38 & 8.74 & 7.07 & 11.11 & \\
\hline Total & Frequency & $\mathbf{2 4 2 9}$ & $\mathbf{1 9 1 1}$ & $\mathbf{1 9 8}$ & $\mathbf{1 3 5}$ & $\mathbf{4 6 7 3}$ \\
\hline
\end{tabular}

Out of the total study population of 4,673 students, 3,322 (71\%) earned the probation status on their first semester and $830(18 \%)$ on their second semester. More than $94 \%$ (4,399 students) earned their probation status within the first three semesters. Only about 3\% of students earn a probation status on or after their third fall semester, an indication that by this time retained students are those in good academic standing. We found that 1,911 students (41\%) were Immediate Takers and 333 students $(7 \%)$ were Late Takers. Of these Late-Takers, $80 \%$ of these delayed taking the course by two semesters or less. We found that 2,429 students $(52 \%)$ did not take the course at all. 
Thus, most students placed on probation incur this intervention after the first semester at IUB. If they comply with the rule to enroll in the Phoenix Program, most will take the course in the correct semester, which is the one immediately after incurring probation status. Since a relatively small number of credits will have been completed in this first year, a student can make significant GPA improvement in a short amount of time.

For all of these cohorts, we also tracked how many students were still enrolled at the university two, four and six, semesters after their cohort term, academic standing at all points (i.e., on probation, in dismissal, or in good standing), and, for some of the earliest matriculation cohorts (2008 through 2010), four- and six-year graduation rates (see Table 2 for descriptive statistics). These data points were accessed, organized, and visualized using Tableau and analyzed using SAS.

Table 2. Timing of EDUC-X158 enrollment status and outcome at different time-marks. "Note: "Negative" indicates a student who is not enrolled, 'Positive' a student who is enrolled or graduated.

\begin{tabular}{|c|c|c|c|c|c|c|c|c|c|c|}
\hline $\begin{array}{l}\text { EDUC- } \\
\text { X158 } \\
\text { Timing }\end{array}$ & & $\begin{array}{l}\text { After } 2 \\
2008-201 \\
\text { Negative }\end{array}$ & $\begin{array}{l}\text { years ( } \\
\text { Positive }\end{array}$ & $\begin{array}{l}\text { ohorts } \\
\text { Total }\end{array}$ & $\begin{array}{l}\text { After } 4 \\
\text { 2008-201 } \\
\text { Negative }\end{array}$ & $\begin{array}{l}\text { years (C } \\
\text { j) }\end{array}$ & $\begin{array}{l}\text { ohorts } \\
\text { Total }\end{array}$ & $\begin{array}{l}\text { After } 6 \\
2008 \text { or } \\
\text { Negativ } \\
\text { e }\end{array}$ & $\begin{array}{l}\text { ears (Co } \\
\text { Positive }\end{array}$ & $\begin{array}{l}\text { ort of } \\
\text { Total }\end{array}$ \\
\hline $\begin{array}{l}\text { Imm. } \\
\text { Takers }\end{array}$ & $\begin{array}{l}\text { Freq } \\
\text { Row } \\
\text { Pct } \\
\text { Col } \\
\text { Pct }\end{array}$ & $\begin{array}{l}810 \\
42.39 \\
30.37\end{array}$ & $\begin{array}{l}1101 \\
57.61 \\
54.89\end{array}$ & 1911 & $\begin{array}{l}659 \\
58.68 \\
36.01\end{array}$ & $\begin{array}{l}464 \\
41.32 \\
58.44\end{array}$ & 1123 & $\begin{array}{l}228 \\
59.53 \\
39.93\end{array}$ & $\begin{array}{l}155 \\
40.47 \\
65.96\end{array}$ & 383 \\
\hline $\begin{array}{l}\text { Late- } \\
\text { Takers }\end{array}$ & $\begin{array}{l}\text { Freq } \\
\text { Row } \\
\text { Pct } \\
\text { Col } \\
\text { Pct }\end{array}$ & $\begin{array}{l}140 \\
42.04 \\
5.25\end{array}$ & $\begin{array}{l}193 \\
57.96 \\
9.62\end{array}$ & 333 & $\begin{array}{l}107 \\
56.32 \\
5.85\end{array}$ & $\begin{array}{l}83 \\
43.68 \\
10.45\end{array}$ & 190 & $\begin{array}{l}32 \\
62.75 \\
5.6\end{array}$ & $\begin{array}{l}19 \\
37.25 \\
8.09\end{array}$ & 51 \\
\hline $\begin{array}{l}\text { Non- } \\
\text { Takers }\end{array}$ & $\begin{array}{l}\text { Freq } \\
\text { Row } \\
\text { Pct } \\
\text { Col } \\
\text { Pct }\end{array}$ & $\begin{array}{l}1717 \\
70.69 \\
64.38 \\
\end{array}$ & $\begin{array}{l}712 \\
29.31 \\
35.49 \\
\end{array}$ & 2429 & $\begin{array}{l}1064 \\
81.16 \\
58.14 \\
\end{array}$ & $\begin{array}{l}247 \\
18.84 \\
31.11\end{array}$ & 1311 & $\begin{array}{l}311 \\
83.6 \\
54.47\end{array}$ & $\begin{array}{l}61 \\
16.4 \\
25.96\end{array}$ & 372 \\
\hline Total & Freq & 2667 & 2006 & 4673 & 1830 & 794 & 2624 & 571 & 235 & 806 \\
\hline
\end{tabular}

For those students who did take the course, in order to determine the impact, if any, of these various demographics and measures of academic preparation on student success, we applied backward elimination logistic regression analysis, with the effect "EDUC-X158 Timing" forced into the model, gender, ethnicity, first generation status, Pell eligibility, official residency, if the student is a new student or transfer, time of probation from student cohort term, high school GPA, SAT score and probation GPA as the other effects, and 'Negative' or 'Positive' status as dependent variable.

But we also filtered this data according to a range of demographic measures to dive deeper into the question of which groups of students are more often heeding the requirement to take the 
course in the first place - as well as the timing of their taking the course - vs. those who do not take it at all. We further contextualized this data vs. the demographic population of the broader student body. This inquiry thus situates our data with respect to several important questions: Are there some groups of students at our institution who are more consistently falling into academic probation than others? Given that the requirement to take the class is only loosely enforced, are certain groups of students on academic probation more likely to take it? Even more specifically, are any of these students more likely to take it at the recommended time than others? The answers to these questions could mean that any impact provided by the course that we measure and discuss here is systematically benefitting some groups of students more than others.

Most probationary students self-identify as male (2,993 students, or 64\%). This is a higher percentage proportional to the general UD student body where males make up about $49 \%,{ }^{1}$ though it is similar to gender trends noted at other higher education institutions (Mattson, 2007; Mathies et al., 2006; Kamphoff et al., 2006). In general, females are more likely to take the course at the recommended time than males (Chi-Square $=6.5, p=0.03$ ). Most students in the course are Indiana residents (3,269 students, or $70 \%$ ), but non-resident students are more likely to be Late-Takers than would be expected (Chi-Square $=29.27, p<0.0001$ ). Self-identified first generation students are a sizable portion of the student population of the course, though not the majority $(1,738$ students, or $37 \%$ ), and are more likely to be Non-Takers (Chi-Square $=10.7, p=0.005$ ). Similarly, while many students are Pell-eligible, they are not the majority (1,429 students, or 31\%), and are more likely to be Non-Takers (Chi-Square $=12.1, p=0.002)$.

Certain ethnic groups are disproportionally represented among those in probationary status. Black and Hispanic students have greater proportional presence in the probation pool compared to the general UD student body (10\% and 5\% against 5\% and $4 \%$ respectively), an indication of further need that corresponds to findings at other institutions (Baker, 2013; Baker \& B. Robnett, 2012; Nonce, 2007; Mathies et al, 2006; Monzon, 2003; Kuh \& Love, 2000). ${ }^{2}$ In terms of taking the Phoenix Program course, Black students tend to be more likely to be Non-Takers, a behavior they share with nonresident aliens, and opposite that of white students (Chi-Square $=79.8, p<0.0001$ ).

Immediate Takers, Late-Takers, and Non-Takers do not appear to have a significantly different high school GPA (mean 3.25), while Late-Takers appear to have a barely, but significantly, higher SAT score compared to the other two groups (ANOVA F $=2.92, p=0.05$ ). However, the GPA that earned the student her/his probation status does appear to be associated with whether the student enrolls in the Phoenix Program. Immediate Takers and Late-Takers tend to have a probation GPA higher than Non-Takers (ANOVA F $=43.47, p<0.0001$ ). Thus, while the Immediate Takers, Late-Takers, and Non-Takers have approximately similar academic scores from high school, they do not have the same GPA scores causing probation. Students are more likely to take the Phoenix course if they are closer to the 2.00 GPA threshold for being in positive standing (on a 4.00 scale).

In sum:

- Our male, Black, and Hispanic students are proportionally more represented among the academic probation population vs. the general student body at our institution.

- More First generation, Pell-eligible, Black, non-resident alien students, and students with a GPA further away from the 2.00 threshold who are on academic probation choose not to take the course and thus do not benefit from the intervention this course provides.

\footnotetext{
${ }^{1}$ Source: Indiana University Bloomington, University Division records (2008-2015), N = 56,531.

2 Source: Indiana University Bloomington, University Division records (2008-2015), N = 56,531.
}

Journal of the Scholarship of Teaching and Learning, Vol. 19, No. 4, October 2019. josotl.indiana.edu 
- Male and non-resident students are more likely to be Late-Takers, which could mean they see a smaller impact from the course vs. those who take the course when recommended (see Results and Discussion below).

Our Results and Discussion section focuses on the broad impact for those who did take the course.

\section{Results and Discussion}

We found a significant and positive correlation between enrollment in EDUC-X158 and persistence and graduation rates.

\section{Persistence}

Figure 1 shows retention rates for Takers and Non Takers in different matriculation cohorts after two semesters. The Takers show persistence rates hovering around $70 \%$, while Non-Takers show a rate around $50 \%$. This is a very positive effect, given that the national average for two-semester retention of all students (regardless of probationary standing) at a four-year institution in the United States is $73.8 \%$ (National Center for Education Statistics, 2016).

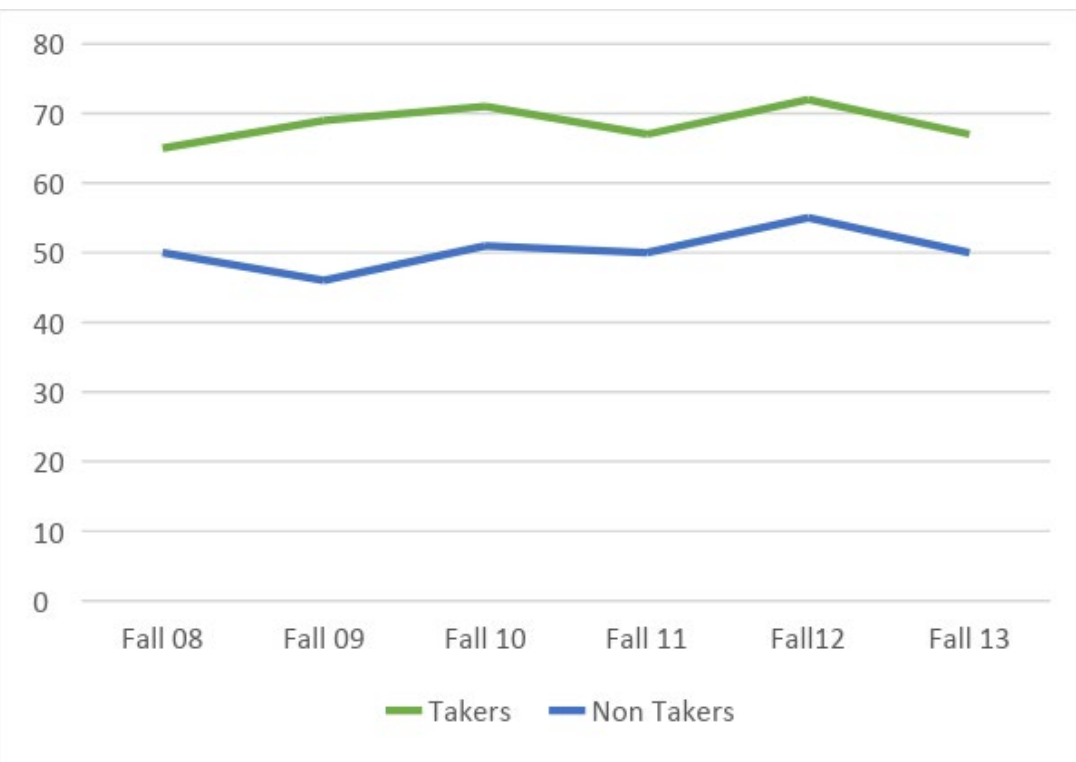

Figure 1. Percent retained after 2 semesters

Essentially, the course encourages more probation students to try and correct their trajectory, and thus to remain enrolled.

This persistence trend continued as we looked at smaller populations placed on probation several years ago. At IUB after two years, for students who earned probation, about 55\% of Takers were still enrolled. This rate dropped to about 35\% for Non-Takers, indicating a possible long-term positive effect of taking the Phoenix Program course. After four years, about 58\% of the Takers remained enrolled or had graduated, while only $31 \%$ of the Non-Takers remained enrolled or had graduated. At six years, the difference increases again: about $66 \%$ of Takers remained enrolled or had graduated, but only $26 \%$ of Non-Takers remained enrolled or had graduated. Thus, at every metric 
point the proportion of Takers with a positive result increased, but the percent of Non-Takers with a positive result decreased.

Logistic regression allowed us to test whether taking the course had still a significant positive effect on student success, while controlling for the variables described above. The results in Table 3 (See Appendix 1) show that students who do not take the course (Non-Takers) have $73 \%$ lower odds of still being enrolled or having graduated after two years compared to students who take the remedial course on time. The strong negative impact of not taking the course is significant and long term, even if it decreases after four years and six years (Non-Takers have 65\% and 67\% lower odds to be enrolled or having graduated than Takers respectively). Non-resident students, non-first generation students and those coming with a higher high school GPA have all significant positive contribution to student success after two years. As expected, entering probation with a higher cumulative GPA results in the greater contribution to increase in the odds of success $354 \%$ higher odds for each GPA point increase).

We also analyzed the relationship between the term students fell into Academic Probation and the term they chose to take EDUC-X158. Unsurprisingly, we found that if students are put on academic probation in their first semester at IUB, they have the best chance of correcting their situation and graduating. This makes sense since students who fall into Academic Probation, which is based on cumulative GPA, later in their careers at IUB will have a larger deficit to overcome. This effect becomes particularly significant after four and six years.

The model does not appear to show that different ethnic groups respond differently to the course.

\section{Retention and Graduation After Four and Six Years}

For some of the earlier cohorts, enough time had passed to determine long-term impact on retention and graduation rates. We found that within the 2008 through 2010 cohorts of students placed on Academic Probation ( $n=2,624)$, about $17 \%$ had graduated after four years. This is a small number, but anticipated since many students who go on probation will usually lose credits to $\mathrm{D}$ and $\mathrm{F}$ grades and thus may have to retake courses, thereby losing time. After six years, $27 \%$ had graduated. We further found that Takers are far more likely to complete a degree: graduation rates for Takers is $26 \%$ versus $9.5 \%$ for Non-Takers after four years, and 39\% and $15 \%$ respectively after six years.

Taking the course has a positive impact on student success at two, four, and six years. Students without the Phoenix Program course have 65\% and 67\% smaller odds of being in a positive standing after four and six years respectively. However, first generation students, Pell eligible students and resident students who enter probation status appear to be at higher risk of not graduating or enrolled after four and six years.

While the model did not indicate the presence of an interaction effect between taking the course and ethnic self-identification, we did see interaction in other demographic characteristics. We tracked the 2008 and 2009 cohorts self-reported First Generation status in the course (Figure 2; $\mathrm{N}=556$ ). The course correlated with greater graduation numbers among this special subset of the student population. Of 330 Takers, 109 graduated by six years (33\%). Of 226 Non-Takers, only 43 graduated by six years $(19 \%)$.

Journal of the Scholarship of Teaching and Learning, Vol. 19, No. 4, October 2019. josotl.indiana.edu 


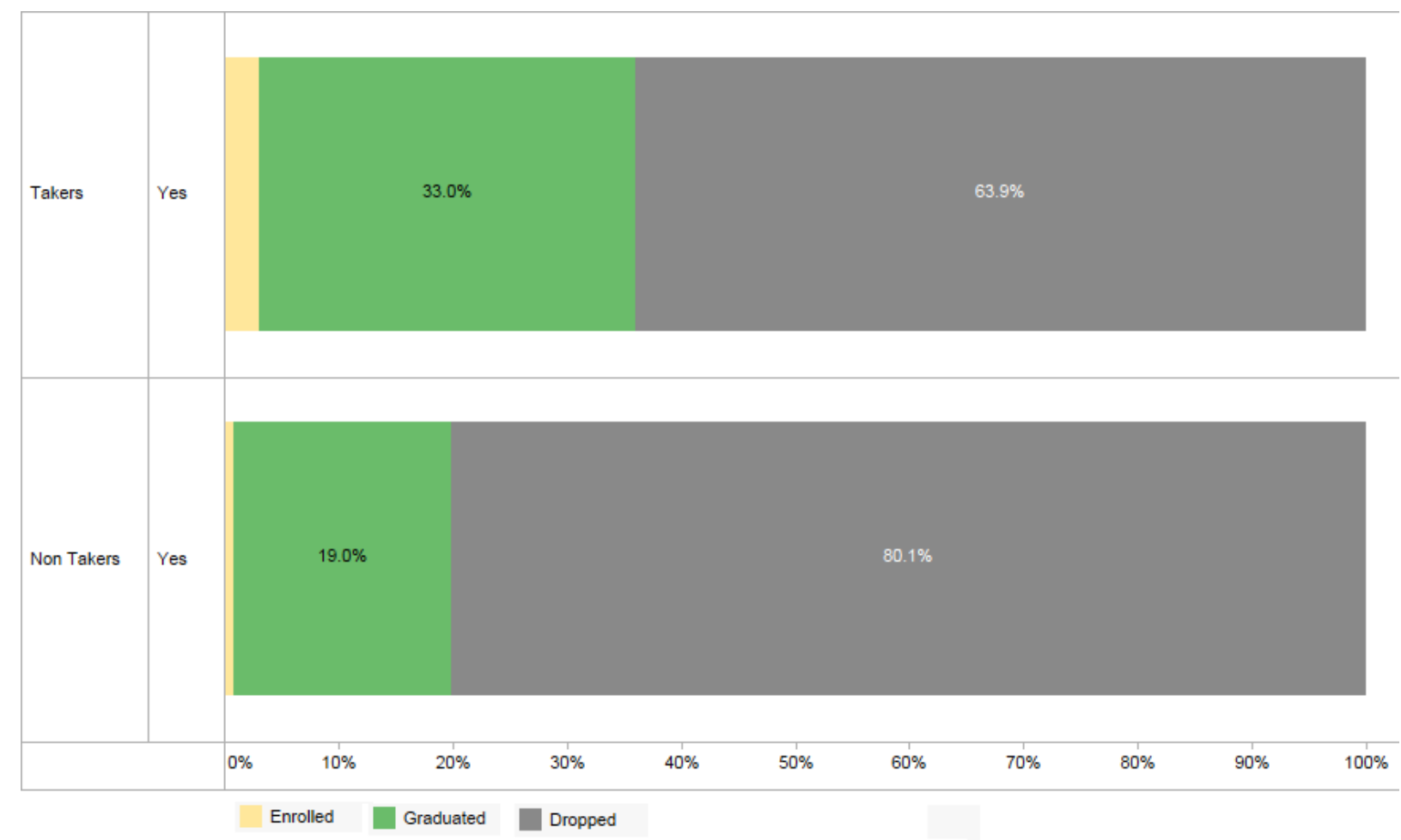

Figure 2. Percent Graduated by First Generation Status after 6 Years

Tracking 2008 and 2009 cohorts Pell-Eligible students revealed the same approximate trend: Takers graduated more often than Non-Takers (Figure 3; N=417). Of 239 Takers, 70 graduated within six years $(29.3 \%)$. Whereas of 178 Non-Takers, only 33 graduated within six years $(18.5 \%)$.

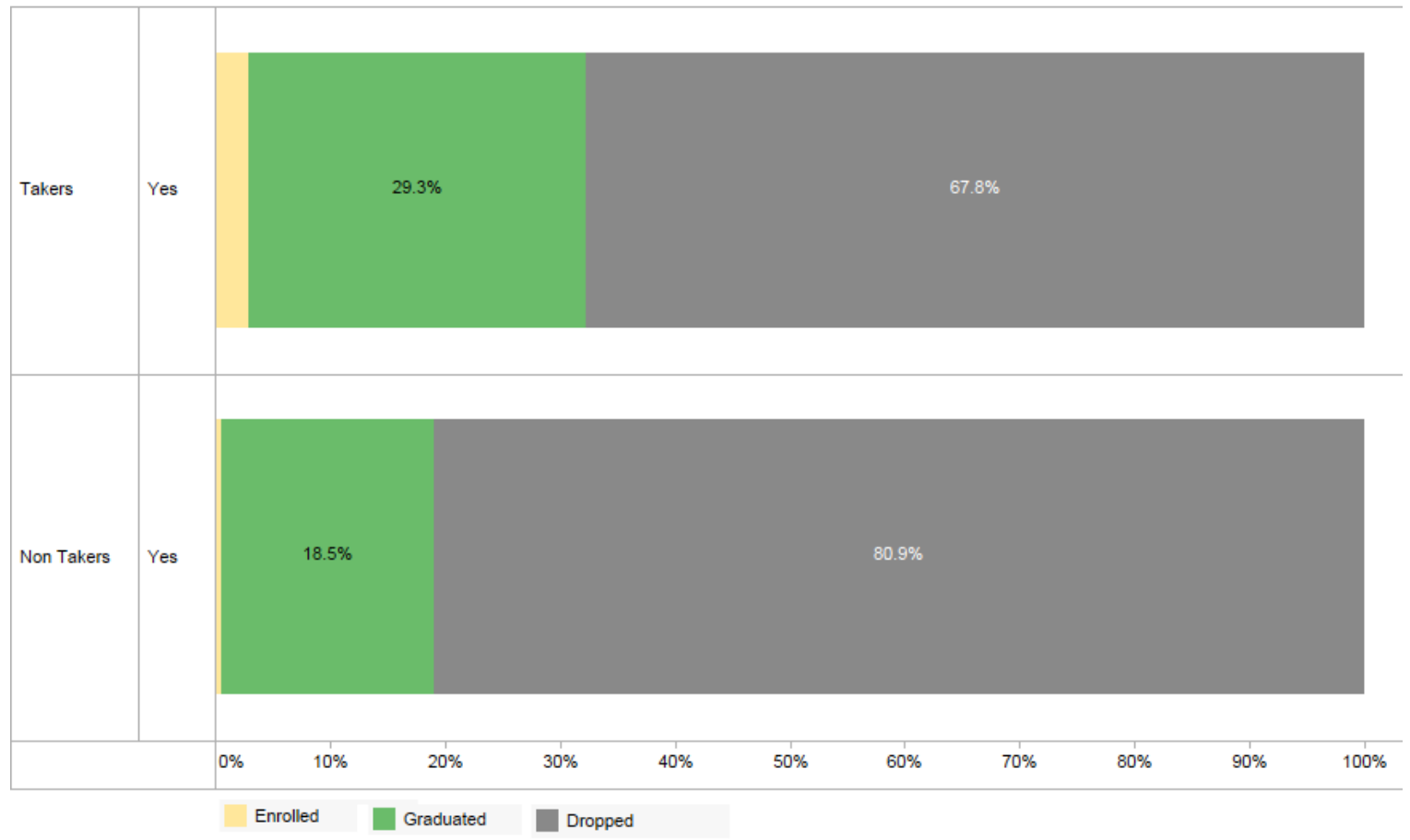

Figure 3. Percent Graduated by Pell-Eligible Status after 6 Years

Journal of the Scholarship of Teaching and Learning, Vol. 19, No. 4, October 2019. josotl.indiana.edu 
In general, women were more likely to graduate than men, whether Takers or Non-Takers. Further, for either gender in the 2008 and 2009 cohorts, Takers were more likely to graduate (Figure 4; $\mathrm{N}=1,471)$. The gap between the graduation rates of the female Takers and Non-Takers $(20.2 \%)$ is greater than the gap between the graduation rates of the male Takers and Non-Takers (around 16.6\%), suggesting that the class makes more of a difference when it comes to female students. As noted above, female students are more likely to take the class, and at the required time, than male students.

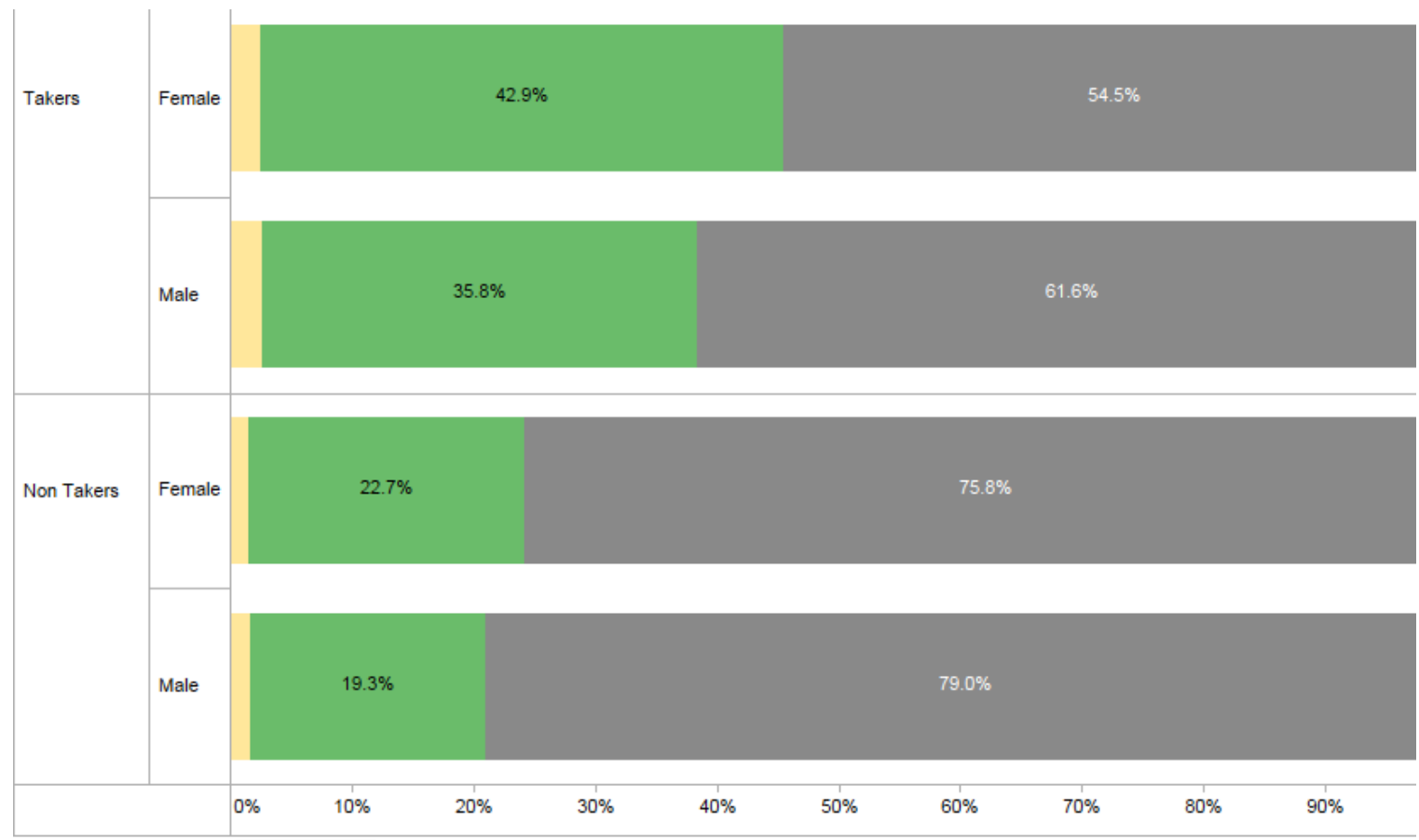

Figure 4. Percent Graduated by Gender after 6 Years

Finally, we found that when a student earned probation status and took the probation course mattered as well. Delaying the Phoenix Program class does not appear to negatively affect the odds of being in positive standing after four years, however this group of student represent a minority of the overall population. Entering probation later in a student career reduces the odds of being in positive standing after four and six years by $20 \%$ and $29 \%$ respectively. Compared to the more than $39 \%$ overall six year graduation rates for the takers of cohort of Fall 2008 through 2010, the Late-Takers graduated only at a rate of about $29 \%$. This is still higher than the Non-Takers. Despite the small negative impact on time to graduation of Late-Takers, this behavior should be discouraged because of their situation: Late-Takers are students who remained on Academic Probation for more than two semesters. A Late-Taker is a student who ignored the first instructions to take the course. If the student improved their GPA enough on their own, they would have no need to take the course and the hold would be removed. This student becomes a Non-Taker. However, if they did not improve their GPA on their own, they would once again be on probation and would receive a second (or more) probation hold. At this point the student may elect to take the course, but will be flagged as a Late-Taker since the course was not completed at the initial instance. Such a student has a significantly higher GPA deficit to overcome, resulting in lower graduation rates.

Several issues become evident by this statistical analysis. First, it is difficult for students placed on probation to graduate, even after six years. Without intervention, most students will drop out, although it may take some time for a student to come to this conclusion, resulting in increased GPA 
deficits and costs. Second, with an intervention class like that in the Phoenix Program and its EDUCX158 course, enrolled students have a much larger chance of correcting habits and trajectory. Finally, all students benefit from the course, including first generation and Pell eligible students.

\section{Conclusion}

As academics working with one of our most vulnerable populations, the authors seek to better understand the full impact of the programming we design to help students on Academic Probation. This means our efforts to evaluate how well we are doing must go beyond a short-term focus on retention alone. To capture the full story of what happens to these students at our institutions we must follow their paths all the way through to graduation - or not, as the case may be.

It is to this end that we offer here specific institutional-level quantitative data about retention and graduation. Our research shows that our required, credit-bearing EDUC-X158 course for students on Academic Probation at IU Bloomington, with a curriculum focused on the purpose and motivation, keeps them here longer and helps them graduate in significantly greater numbers over those probation students who do not take the course. Over time, thousands of students that take this class are learning how to recover from setbacks, meet challenging long-term goals as they complete their degrees, and move on to their adult lives and careers.

Looking at long-term probation trajectories also helps one view probation students differently. Probation status has an ignoble reputation among administrators and faculty, as if probation students are "bad" students, or as one tenured faculty member told us, the "dregs of the university." Perhaps this is because of the word "probation," which is associated with law and lawbreakers in the wider US culture. But we see probation students differently. These are students who, given the right support network, can learn about themselves, their habits, and their trajectories; students who can correct selfhandicapping habits and issues; and students who can graduate. Probation, then, becomes not a marker of a "bad" student, but rather an early warning system that informs a student that his/her current habits are not up to the standards of the institution. We see it as a wake-up call for our institutions, instructors, and students themselves - not a marker of intelligence, character, or potential.

\section{Acknowledgements}

The authors would like to thank the Indiana University, Bloomington, Center for Innovative Teaching and Learning and the Office of the Vice Provost for Undergraduate Education who provided a Learning Analytics Grant to fund the research. Further, Bloomington Assessment and Research assisted with data collection and the creation of the Tableau data mining workbooks. Adrienne Sewell, University Division Director of Advising for Retention and Sophomore Initiatives, provided historical background for the Phoenix Program. Finally, we would like to thank Student Academic Center Director Dr. Charles R. Frederick, Jr. for his ongoing mentorship and support.

Journal of the Scholarship of Teaching and Learning, Vol. 19, No. 4, October 2019. josotl.indiana.edu 


\section{Appendix}

Appendix 1. Table 3: Model estimates of "Positive" (I.E. being enrolled or having earned a degree) outcome after the second year, the fourth year and the sixth year.

\begin{tabular}{|c|c|c|c|c|c|c|c|c|c|c|c|c|}
\hline \multirow[b]{2}{*}{ Predictor } & \multicolumn{4}{|c|}{ After 2 years (Cohorts 2008-2012) } & \multicolumn{4}{|c|}{ After 4 years (Cohorts 2008-2010) } & \multicolumn{4}{|c|}{ After 6 years (Cohort of 2008 only) } \\
\hline & $B$ & $S E B$ & Prob & $O R$ & 8 & $S E B$ & Prob & $O R$ & 8 & $S E B$ & Prob & $O R$ \\
\hline Intercept & -2.3087 & 0.4288 & $<.0001$ & & -1.4690 & 0.5112 & 0.0041 & & -0.3179 & 0.9006 & 0.7241 & \\
\hline Delayed remedial & 0.4600 & 0.0903 & $<.0001$ & 1.0360 & 0.4774 & 0.1192 & $<.0001$ & 1.2080 & 0.2384 & 0.2331 & 0.3064 & 0.8220 \\
\hline No remedial & -0.8849 & 0.0598 & $<.0001$ & 0.2700 & -0.7659 & 0.0828 & $<.0001$ & 0.3480 & -0.6727 & 0.1587 & $<.0001$ & 0.3310 \\
\hline SAT & -0.0007 & 0.0003 & 0.0286 & 0.9990 & -0.0011 & 0.0004 & 0.0049 & 0.9990 & -0.0022 & 0.0007 & 0.0022 & 0.9980 \\
\hline Probation GPA & 1.5128 & 0.0912 & $<.0001$ & 4.5400 & 1.5136 & 0.1410 & $<.0001$ & 4.5430 & 1.5138 & 0.2546 & $<.0001$ & 4.5440 \\
\hline Official residence (Non resident) & 0.2160 & 0.0448 & $<.0001$ & 1.5400 & 0.2002 & 0.0625 & 0.0014 & 1.4920 & 0.2657 & 0.1109 & 0.0166 & 1.7010 \\
\hline First generation [Not first generation) & 0.1405 & 0.0393 & 0.0003 & 1.3240 & 0.1643 & 0.0561 & 0.0034 & 1.3890 & & & & \\
\hline High school GPA & 0.1960 & 0.0990 & 0.0477 & 1.2170 & & & & & & & & \\
\hline Time of probation from first term & & & & & -0.2180 & 0.0511 & $<.0001$ & 0.8040 & -0.3386 & 0.0986 & 0.0006 & 0.7130 \\
\hline Pell eligibility (Not Pell eligible) & & & & & 0.1231 & 0.0598 & 0.0397 & 1.2790 & 0.3555 & 0.1159 & 0.0022 & 2.0360 \\
\hline Observations* & 3839 & & & & 2228 & & & & 709 & & & \\
\hline \multicolumn{13}{|l|}{ Model Fit Statistics } \\
\hline Criterion & Intercept Only & \multicolumn{2}{|c|}{ Intercept and Covariates } & & Intercept Only & \multicolumn{2}{|c|}{ Intercept and Covariates } & & Intercept Only & \multicolumn{2}{|c|}{ Intercept and Covariates } & \\
\hline AIC & 5196.73 & \multicolumn{2}{|r|}{4405.68} & & 2713.08 & \multicolumn{2}{|r|}{2386.29} & & 867.02 & \multicolumn{2}{|r|}{757.46} & \\
\hline sc & 5202.99 & & 4455.71 & & 2718.79 & \multicolumn{2}{|r|}{2437.67} & & 871.58 & \multicolumn{2}{|r|}{816.79} & \\
\hline$-2 \log L$ & 5194.73 & & 4389.68 & & 2711.08 & \multicolumn{2}{|r|}{2368.29} & & 865.02 & \multicolumn{2}{|r|}{731.46} & \\
\hline \multicolumn{13}{|l|}{ Testing Global Null Hypothesis: BET $A=0$} \\
\hline Test & Chi-Square & DF & $\mathrm{Pr}>\mathrm{ChiSq}$ & & Chi-Square & DF & $\mathrm{Pr}>\mathrm{ChiSq}$ & & Chi-Square & DF & $\mathrm{Pr}>\mathrm{ChiSq}$ & \\
\hline Likelihood Ratio & 805.05 & 7 & $<.0001$ & & 342.79 & 8 & $<.0001$ & & 124.64 & 7 & $<.0001$ & \\
\hline Score & 701.95 & 7 & $<.0001$ & & 294.96 & 8 & $<.0001$ & & 107.22 & 7 & $<.0001$ & \\
\hline Wald & 580.45 & 7 & $<.0001$ & & 253.63 & 8 & $<.0001$ & & 91.28 & 7 & $<.0001$ & \\
\hline
\end{tabular}




\section{References}

American Institute of Research (AIR). (2010). 4-year college data tool. Retrieved from http://collegemeasures.org

Astin, A. W. (1984). Student involvement: a developmental theory for higher education. Journal of College Student Personnel, 25, 297-308.

Baker, C. N. (2013). Social support and success in higher education: The influence of on-campus support on African American and Latino college students. The Urban Review, 45(5), 632-650. doi:10.1007/s11256-013-0234-9

Baker, C. N., \& Robnett, B. (2012). Race, social support and college student retention: A case study. Journal of College Student Development, 53(2), 325-335. doi: 10.1353/csd.2012.0025

Baker, S. R. (2004). Intrinsic, extrinsic, and amotivational orientations: Their role in university adjustment, stress, well-being, and subsequent academic performance. Current Psychology, 23(3), 189-202. doi:10.1007/s12144-004-1019-9

Bell, I. (2013). This book is not required: An emotional and intellectual survival manual for students. Thousand Oaks, CA: Sage.

Borrego, A.M. (2002, July 12). Education department will emphasize student retention issues in next Higher Education Act, official says. The Chronicle of Higher Education. Retrieved from http://chronicle.com/article/Education-Dept-to-Emphasize/18268/

Braxton, J., Brier, E., \& Steele, S. (2007-2008). Shaping retention from research to practice. Journal of College Student Retention: Research, Theory \& Practice, 9(3), 377-399. doi: 10.2190/CS.9.3.g

Brooks, K. (2009). You majored in what? Mapping your path from chaos to career. New York, NY: Plume.

Cohen, A., \& Brawer, F. (2002). The American community college (4 ${ }^{\text {th }}$ ed.). San Francisco, CA: JosseyBass.

Cruise, Christie A. (2002). Advising Students on Academic Probation. The Mentor, 4 (4).

Deci, E. L., \& Ryan, R. M. (1985). Intrinsic motivation and self-determination in buman behavior. New York, NY: Plenum.

Delbanco, A. (2012). College: What it was, is, and should be. Princeton, NJ: Princeton University Press.

Demetriou, C., \& Schmitz-Sciborski, A. (2011). Integration, motivation, strengths, and optimism: Retention theories past, present, and future. In R. Hayes (Ed.), Proceedings of the $7^{\text {th }}$ National Symposium on Student Retention, 2011, Charleston (pp. 300-312). Norman, OK: The University of Oklahoma.

Downing, S. (2014). On Course: Strategies for creating success in college and in life. Boston, MA: Wadsworth.

Dweck, C. (2006). Mindset: The new psychology of success. New York, NY: Random House.

Dynarski, M., \& Gleason, P. (2002). How can we help? What we have learned from federal drop-out prevention programs. Journal of Education for Students Placed At-Risk, 7(1), 43-69. doi:10.1207/S15327671ESPR0701_4

Florczak, K.L. (2014). Purists need not apply: The case for pragmatism in mixed methods research. Nursing Science Quarterly, 27(4), 278-282.

Garnett, D.T. (1990). Retention strategies for high risk students at a four-year university. NACADA Journal, 10(1), 22-25. doi:10.12930/0271-9517-10.1.22

Hamman, K. (2016). Factors that contribute to the likeliness of academic recovery. Journal of College Student Retention: Research, Theory \& Practice, O(0), 1-14. doi:10.1177/1521025116652636

Hanger, M. A, Goldenson, J., Weinberg, M., Schmitz-Sciborski, A., \& Monzon, R. (2011). The bounce back retention program: One-year follow-up study. Journal of College Student Retention: Research, Theory \& Practice, 13(2), 205-227. doi:10.2190/CS.13.2.d 
Hebel, S. (2003, May 15). California colleges face smaller cuts in governor's revised state budget plan. The Chronicle of Higher Education. Retrieved from http://chronicle.com/article/CaliforniaColleges-Face/110342

Hsieh, Peggy, Sullivan, Jeremy R., \& Guerra, Norma S. (2007). A closer look at college students: SelfEfficacy and Goal Orientation. Journal of Advanced Academics, 18(3), 454-476.

Humphrey, E. (2005). Project Success: Helping probationary students achieve academic success. Journal of College Student Retention: Research, Theory \& Practice, 7(3-4), 147-163. doi:10.2190/AMQ4-13VE-RBH7-6P1R

Kamphoff, C. S., Hutson, B. L., Amundsen, S. A., \& Atwood, J. A. (2006-2007). A motivational/empowerment model applied to students on academic probation. Journal of College Student Retention: Research, Theory \& Practice, 8(4), 397-412. ～doi:10.2190/96528543-3428-1J06

Kuh, G. D., \& Love, P. G. (2000). A cultural perspective on student departure. In. J. M. Braxton (Ed.), Reworking the student departure puzzle (pp. 196-212). Nashville, TN: Vanderbilt University Press.

Lin, Y.-G., \& McKeachie, W. J. (1999). College student intrinsic and/ or extrinsic motivation and learning. Washington, D.C.: American Psychological Association.

Mathies, C., Gardner, D., \& Bauer, K. W. (2006). Retention and graduation: An examination of students who earn academic probation. Paper presented at 2006 Southern Association for Institutional Research Forum, Arlington, VA.

Mattson, C. E. (2007). Beyond admission: Understanding pre-college variables and the success of at-risk students. Journal of College Admission, 196, 9-13.

Mellor, David T., Brooks, W., Gray, S., \& Jordan, R. (2015). Troubled transitions into college and the effects of a small intervention course. Journal of College Student Retention: Research, Theory do Practice, 17(1), 44-63. doi:10.1 177/15210251 15571102

Miller, K., \& Sonner B. (1996). PASS: Promoting academic student success. Final report.

Monzon, R. (2003). Integration and persistence of Filipino American college students: The mediating effects of family obligation and reputation. Unpublished doctoral dissertation, San Diego State University.

National Center for Education Statistics. (2016). IPEDS trend generator: Graduation and retention rates [data file]. Retrieved from http://nces.ed.gov/ipeds/trendgenerator/

Nonce, M. (2007). The psychological impact of academic probation. Diverse: Issues in Higher Education, 24(19), 12.

Ormerod, R. (2006). The history and ideas of pragmatism. Journal of the Operational Research Society, 57, 892-909.

Quinton, S. (2015, December 31). States to colleges: Prove you're worth it. Stateline. Retrieved from http://www.pewtrusts.org/en/research-andanalysis/blogs/stateline/2015/12/31/best-of-stateline-states-to-colleges-prove-youre-worthit

Rich, A. (1979). On lies, secrets and silence. New York, NY: Norton.

Salinitri, G. (2005). The effects of formal mentoring on the retention rates for first-year, low achieving students. Canadian Journal of Education, 28(4), 853-873. doi:10.2307/4126458

Stratford, M. (2015, September 14). The new college scorecard. Inside Higher Ed. Retrieved from https://www.insidehighered.com/news/2015/09/14/obama-administration-publishes-newcollege-earnings-loan-repayment-data

Strauss, A., \& Corbin, J. (1990). Basics of qualitative research: Grounded theory procedures and techniques. Newbury Park, CA: Sage. 
Thayer, P.B. (2000). Retention of students from first-generation and low-income backgrounds. Opportunity Outlook, May, 2-8.

Tovar, E. \& Simon, M.A. (2006). Academic Probation as a dangerous opportunity: Factors influencing diverse college students' success. Community College Journal of Research and Practice, 30(7), 547564.

Tinto, V. (1975). Dropout from higher education: A theoretical synthesis of recent research. Review of Educational Research, 45(1), 89-125. doi:10.3102/00346543045001089

Tinto, V. (2000). Linking learning and leaving: Exploring the role of the college classroom in student departure. In J.M. Braxton (Ed.), Reworking the student departure puzইle (pp. 81- 84). Nashville, TN: Vanderbilt University Press.

Turner, P., \& Thompson, E. (2014). College retention initiatives meeting the needs of Millenial freshman students. College Student Journal 48(1), 94-104.

Worrell, F. C., \& Hale, R. L. (2001). The relationship of hope in the future and perceived school climate to school completion. School Psychology Quarterly, 16(4), 357-369. doi:10.1521/scpq.16.4.370.19896 